
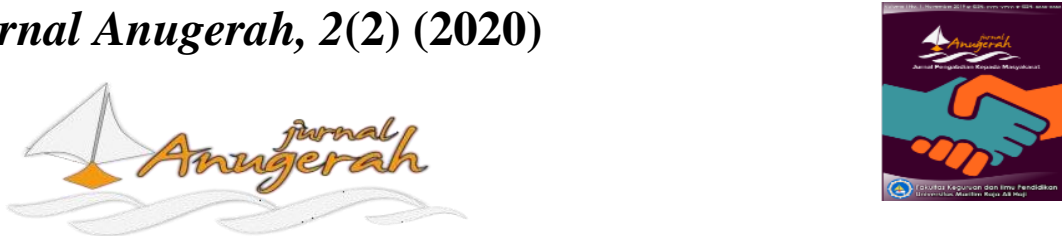

e-ISSN 2715-8179

https://ojs.umrah.ac.id/index.php/anugerah

\title{
Pelatihan Pengembangan Kegiatan Pembelajaran Matematika Berbasis Aplikasi Geogebra Bagi Guru SMA Angkasa Adisutjipto
}

\author{
Rindu Alriavindra Funny \\ Program Studi Teknik Dirgantara \\ Sekolah Tinggi Teknologi Adisutjipto, Yogyakarta, DIY, 55198, Indonesia \\ e-mail korespondensi: $\underline{\text { rindualri@stta.ac.id }}$
}

Pengiriman: 15 Agustus 2020; Diterima: 23 November 2020; Publikasi: 30 November 2020

DOI: https://doi.org/10.31629/anugerah.v2i2.2388

\begin{abstract}
Abstrak
Maraknya siswa menggunakan smartphone di SMA Angkasa Adisutjipto menjadi gangguan utama dalam proses belajar mengajar dikelas. Siswa tidak mendengarkan penjelasan dari guru dan lebih asyik mengecek media sosial atau bahkan bermain game. Hal ini mengakibatkan diberlakukannya aturan untuk menitipkan smartphone kepada Guru Piket setiap hari di beberapa sekolah. Aturan ini menjadi sebuah dilema bagi pihak sekolah terkait kebutuhan dan kebebasan siswa untuk berkomunikasi sehingga butuh suatu alternatif yang dapat menjembatani kebebasan siswa dalam berkomunikasi dan penggunaan smartphone dalam proses pembelajaran dikelas. Oleh karena itu produk dari pengabdian masyarakat ini adalah rencana pelaksanaan pembelajaran (RPP) dengan media pembelajaran berbasis teknologi yaitu aplikasi Geogebra.Tahapan yang dilakukan meliputipengenalan aplikasi-aplikasi dalam matematika, pelatihan dan pendampingan penyusunan RPP berbasis teknologi kepada guru-guru SMA Angkasa Adisutjipto, dan uji coba RPP kepada siswa.Hasil kegiatan pengabdian masyakarat ini gurumemperoleh pengetahuan tentang aplikasi Geogebra, mampu menggunakan aplikasi Geogebra, mampu menyusun rencana pembelajaran (RPP) dengan menggunakan aplikasi Geogebra serta dapat menerapkannyasebagai bentuk blended learning dalam proses pembelajaran dikelas. Selain itu, kinerja siswa pada saat pelaksanaan pembelajaran sesuai RPP sangat memuaskkan. Para siswa sangat cepat beradaptasi dengan fitur-fitur yang ada pada aplikasi Geogebra pada smartphonemasing-masing.Siswajuga jadi antusias selama pembelajaran dan pada proses diskusi.
\end{abstract}

Kata kunci: blended learning; Geogebra; rencana pelaksanaan pembelajaran.

\begin{abstract}
Ashappenedin many schools, the impact of using smartphone during the class also became big issues inSMA Angkasa Adisutjipto. Therefore, the school made rules to put the students' smartphone on the Duty Teacher duringthe school. But it is like banning students' freedom ofcommunication. Therefore, to cope this problem, we trained the teachers to arrange a lesson plan using technology. In the first meeting, teachers were given training about variation of digital learning in mathematics. Afterwards, they chose one of it which suitable with the basic competencies they taught now. Since at that time the class would learn about Geometry Transformation, so they chose Geogebra. Since this training is aimed to show the positive of using smartphone in the class, so we used Geogebra in smartphone version. In the second meeting, teachers were accompanied to make a LessonPlanwithblended learningmethodand useGeogebra application in smartphone. In the third meeting, we simulated the lesson plan on the classroom and evaluated its effectiveness. The result showsthat the teachers are able to operate the application of Geogebra, to combine this technology in the lesson plan to make blended learning and to apply it into the teaching learning process. Furthermore, the students' performance when the lesson plan was testing is very satisfactory. They were able to quicklyadjust with the application. They were more attractive in learning and discussing the material. Thus, thiskind of training is very helpful for teachers as a self-development.
\end{abstract}




\section{JURNAL ANUGERAH, November 2020; Vol2(2): 83 - 92 e-ISSN 2715-8179}

Keywords:blended learning; Geogebra; lesson plan.

\section{Pendahuluan}

Perkembangan teknologi yang sangat pesat saat ini membuat para guru khawatir bahwa mereka tidak akan bisa selamanya melarang siswa menggunakan teknologi di kelas. Perkembangan ini menuntut dunia pendidikan untuk menyesuaikan perkembangan teknologi terhadap usaha dalam peningkatan mutu pendidikan. Hal ini memerlukan inovasi dan kreativitas dari guru dalam pelaksanaan proses pembelajaran dengan mengembangkan sistem pembelajaran yang berbasis teknologi, berorientasi pada siswa, dan memfasilitasi kebutuhan siswa dengan kegiatan pembelajaran yang menantang, aktif, kreatif, inovatif, efektif, serta menyenangkan dengan mengembangkan kegiatan pembelajaran berbasis teknologi(Funny, 2019).

Smartphone adalah salah satu teknologi yang berkembang pesat saat ini. Semua orang, baik orang dewasa, anak - anak, laki - laki atau perempuan memiliki smartphone dan tidak bisa lepas dari smartphone dalam kehidupan sehari-harinya. Terlebih perkembangan penggunaan smartphone yang melejit dari tahun ke tahun berimbas pada kegiatan pembelajaran di kelas. Penelitian menyebutkan bahwa 95\% siswa sekolah membawa smartphonedidalam kelas setiap hari, 92\% siswa sekolah menggoperasikan smartphonenya ketika didalam kelas dan 10\% mengakui mengggunakan smartphone untuk message ketika ujian(Tindell, Deborah R; Bohlander, 2012). Siswa - siswa tersebut berdalih bahwa guru mereka tidak sadar dengan aktivitas mereka dalam siswaan smartphonedikelas. Mereka bahkan bisa browsing, saling berkirim gambar atau mengakses media sosial selama dikelas. Bagi kebanyakan guru hal ini dianggap sangat mengganggu sehingga banyak dari sekolah yang melarang siswanya membawa smartphone selama pembelajaran. Tetapi hal ini ternyata menimbulkan pro dan kontra, karena adanya kebutuhan komunikasi antara siswa dengan orang tua dan kontribusi yang cukup positif bagi siswa untuk menemukan tambahan materi - materi dalam pembelajaran dikelas. Seperti, guru Bahasa inggris bisa meminta siswa untuk menemukan arti dari kata Bahasa Inggris dari google translate atau website terjemahan lainnya daripada memaksa siswa untuk selalu membawa kamus yang terkadang ketinggalan dirumah.

Dalam matematika, sudah banyak aplikasi-aplikasi komputer yang berfungsi sebagai media pembelajaran yang dapat memberikan pengalaman visual kepada siswa ketika berinteraksi dengan objek objek matematika, bahkan saat ini aplikasi tersebut merambah ke dunia android (smartphone). Salah satunya adalah software Geogebra, yaitu salah satu alternatif multimedia pembelajaran matematika yang memberikan pengalaman visual dalam berinteraksi dengan konsep-konsep geometri(Asngari, 2015). Konsep-konsep ini terkadang susah dipahami siswa karena mereka tidak dapat melihat visualisasinya secara nyata, kebanyakan siswa diminta menggambarkan konsep geometri hanya secara sketsa, bukan dalam skala yang asli. Sebelumnya, penggunaan Geogebradikelas sudah sering dilakukan karena dapat menvisualisasikan objekobjek matematika secara cepat, akurat, dan efisien. GeoGebra menampilkan koordinat cartesius yang dapat digunakan untuk menentukan titik-titik koordinat, membuat ruas garis, menggambar bangun datar serta menentukan besar sudut-sudutnya, dan menggambar grafik(Agung, 2018). Tetapi kurangnya fasilitas komputer yang memadai sering menjadi kendala dalam pengaplikasian softwareGeogebra dalam pembelajaran matematika(Oktaviani \& Sholikhakh, 2018). Adanya softwareGeogebra di smartphone menjadi solusi atas fasilitas komputer yang belum memadai di banyak sekolah.

Berdasarkan informasi dari Guru SMA Angkasa Adisutjipto bahwa pembelajaran matematika di kelas XI IPA saat ini adalah materi Transformasi Geometri yang meliputi Translasi, Rotasi, Dilatasi dan lainnya. Geogebra mendukung materi tersebut dalam fitur geometrinya. Oleh karena itu, akan diberikan pelatihan dan pendampingan kepada guru di SMA Angkasa Adisutjipto dalam menyusun RPP blended 
learningpembelajaran transformasi geometri dengan menggunakan aplikasi Geogebra di smartphone siswa serta pendampingan pengaplikasianyadikelas.

\section{Metode}

Kegiatan ini menggunakan metode pendidikan masyarakat, pelatihan serta pendampingan kepada guru di SMA Angkasa Adisutjipto.Pendidikan masyarakat dengan memberikan materi mengenai pengenalan dan penggunaannya melalui ceramah. Metode pelatihan dilakukan dengan mendemonstrasikan Geogebra serta mendampingi guru dalam menyusun RPP pembelajaran blended learning dengan menggunakan aplikasi Geogebra pada materi Transformasi Geometri. Sebanyak 11 guru SMA Angkasa berpartisipasi dalam kegiatan ini, 3 diantaranya adalah guru matematika

Metode pelaksanaan dalam pengabdian masyarakat ini berbentuk pelatihan yaitu pemberian materi, perancangan RPP dan pengaplikasian RPP pada pembelajaran dikelas. Adapun masing-masing materi pada tiap sesi adalah sebagai berikut.

1. Pertemuan 1 (1 November 2020): a) Pengenalan berbagai macam aplikasi-aplikasi matematika baik di PC atau smartphone, b) Praktek penggunaan aplikasi-aplikasi tersebut, c) Diskusi tentang proyek menganalisis aplikasi-aplikasi matematika berbasis android yang beredar umum.

2. Pertemuan 2 ( 8 November 2020): Perancangan kegiatan pembelajaran (RPP) dikelas menggunakan blended learning aplikasi Geogebra dan proyek menganalisis aplikasi-aplikasi matematika berbasis android yang beredar umum.

3. Pertemuan 3 (15 November 2020): a) Praktek rancangan kegiatan pembelajaran (RPP) dikelas menggunakan blended learning aplikasi Geogebra, b) Evaluasi kegiatan pembelajaran blended learning aplikasi matematika yang telah dilaksanakan, c) Evaluasi RPP.

\section{Hasil dan Pembahasan}

\section{Pertemuan 1: Pengenalan dan Pelatihan Digital Learning bagi Guru SMA ANGKASA Adisutjipto}

Kegiatan Pelatihan Guru SMA Angkasa Adisutjipto ini sebagai pelaksanaan dari pertemuan 1 yang bertujuan untuk mengenalkan berbagai macam aplikasi - aplikasi digital learning secara umum. Pelatihan ini dilaksanakan pada tanggal 1 November 2019 di Aula SMA Angkasa Adisutjipto Yogyakarta yang diikuti oleh 11 guru dengan berbagai bidang ilmu. Pada kegiatan ini diisi oleh pengabdi beserta 2 dosen Bahasa Inggris sebagai tim pengabdian masyarakat di SMA Angkasa Adisutjipto ini. Penyampaian materi dilaksanakan secara bergantian kepada guru - guru tersebut beserta pemberian modul. Pada awalnya pelatihan mencakup digital learning secara umum, kemudian akan dispesifikasikan sesuai bidang ilmu seperti gambar 1 dimana penulis memberikan materi digital learning yang biasa digunakan dalam pembelajaran matematika. 


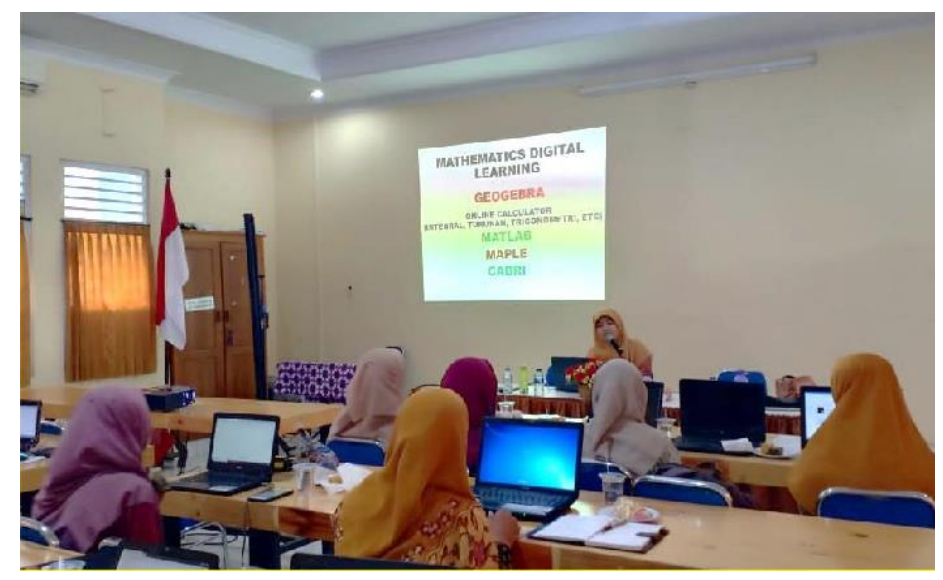

Gambar 1. Pengenalan dan Pelatihan Digital Learning Matematika

Kemudian akan diambil beberapa digital learning yang menarik minat guru - guru SMA tersebut untuk dipelajari lebih lanjut seperti gambar 2 yang sedang memperkenalkan Geogebra.

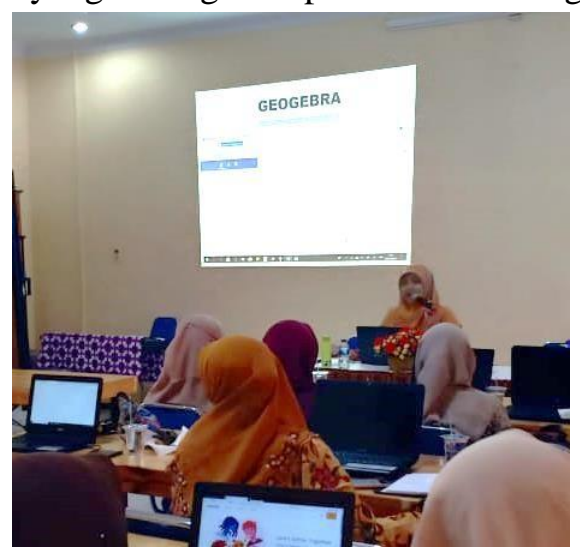

Gambar 2. Pengenalan dan Pelatihan Aplikasi Geogebra

Guru - guru matematika di SMA Angkasa sudah mengetahui tentang aplikasi Geogebra tetapi yang berbasis komputer. Guru - guru tersebut baru mengetahui bahwa ada aplikasi Geogebra di smartphone sehingga bisa dimanfaatkan sebagai media pembelajaran berbasis teknologi. Pemanfaatan smartphone secara optimal pada pembelajaran dikelas dapat mengurangi kecenderungan stigma negatif penggunaan smartphonedi dalam kelasoleh siswa sekolah menengah atas yang salah satunya dikatakan dapat berisiko menurunkan prestasi(Utami, 2019). Sebaliknya bahwa smartphone siswa ternyata dapat dimanfaatkan dengan optimal sebagai media pembelajaran yang sederhana, menarik dan menyenangkan.

\section{Pertemuan 2: Pengembangan Kegiatan Pembelajaran Matematika Berbasis Teknologi bagi Guru Matematika SMA ANGKASA Adisutjipto - Penyusunan RPP.}

Pertemuan ke-2 ini lebih ditekankan pada pengembangan RPP guru SMA Angkasa untuk memasukkan unsur teknologi (blended learning). Kegiatan ini dilaksanakan pada tanggal 8 November 2019 di Aula SMA Angkasa. Bapak Ibu Guru pengajar Matematika diminta untuk membawa salah satu RPP tentang materi yang akan diajarkan di kelas mereka dan akan didampingi oleh penulis. Produk yang dihasilkan dari pertemuan 2 adalah RPP blended Learning. Pada mata pelajaran matematika akan digunakan Aplikasi Geogebra sebagai teknologi dalam pembelajaran blended learning pada materi Transformasi Geometri. Dalam RPP tersebut, siswaakanmengeksplorasismartphone sebagai alat untuk belajar dengan 
menggunakan aplikasi Geogebra.Sebenarnya tidak ada perbedaan yang significant antara tampilan Geogebra pada PC/Laptop dengan di smartphone.
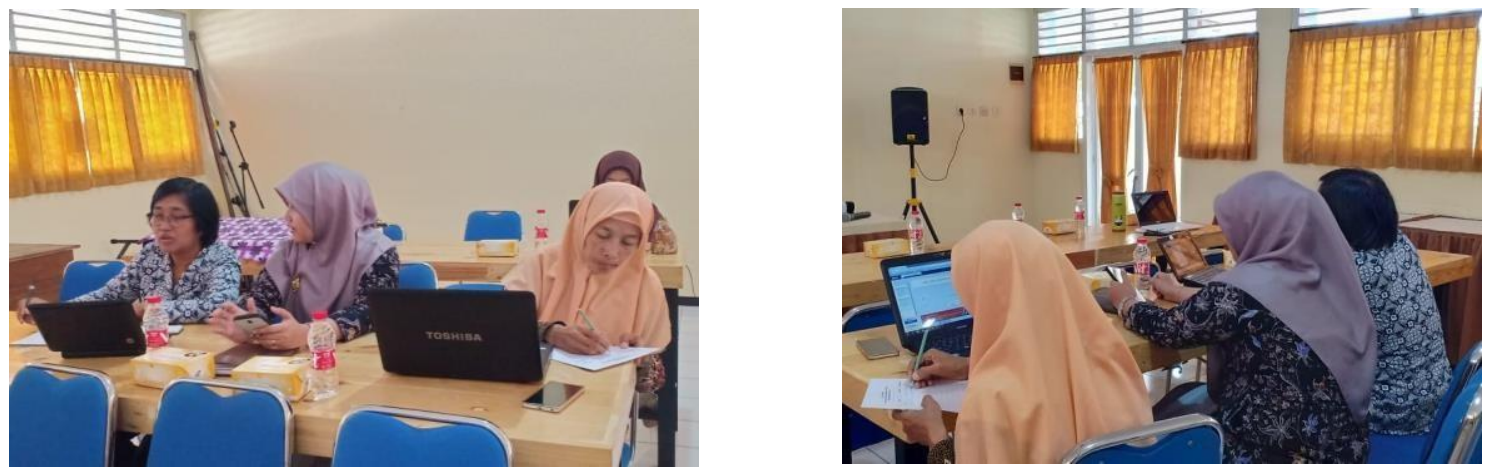

Gambar 3. Pendampingan Pembuatan RPP Kegiatan Pembelajaran Berbasis Teknologi

Pada saat penyusunan RPP, kendala yang paling utama adalah format RPP yang sering berubah ubah, sehingga guru kesulitan mengikutinya, terutama bagi guru - guru yang sudah usia lanjut. Pada akhirnya kami menggunakan format RPP dari salah satu guru matematika yang menang sebagai guru teladan sekolah Angkasa, yaitu Ibu Yulida Ekawati, S.Pd. Si. Kendala lain yang dihadapi dalam menyusun RPP ini adalah menentukan model pembelajaran dengan blended learning. Berdasarkan hasil diskusi, bahwa model pembelajaran inquiry dirasa paling cocok diterapkan dalam RPP ini karena dengan teknologi Geogebra di smartphone siswalah yang harus berperan aktif mengamati, mencoba dan merumuskan sendiri apa saja kegunaan aplikasi tersebut dalam materi yang sedang diajarkan. Demonstrasi menjadi metode utama yang dilakukan dalam pembelajaran ini. Pendekatan yang dilakukan dalam RPP harus berorientasi pada siswa, sehingga pemberian materi penggunaan aplikasi oleh guru harus diminimalisir.

\section{Rencana Pelaksanaan Pembelajaran (RPP)}

Dalam penyusunan RPP, dipilih Kompetensi Dasar (KD) 3.5 yang sesuai dengan fitur yang ada di Aplikasi Geogebra pada smartphone yaitutransformasi dan komposisi transformasidengan indikator siswa mampu melakukan translasi, refleksi, rotasi dan dilatasi pada suatu objek dengan aplikasi Geogebra di smartphone. RPP ini menggunakan pendekatan Saintifik dengan model pembelajaran inquiry. Sedangkan metode yang cocok adalah demonstrasi, diskusi kelompok dan tanya jawab. Hal ini dikarenakan siswa menggunakan alat/media smartphoneyang terhubung dengan internet dan sudah terinstal aplikasi Geogebra.

Pada kegiatan inti dari RPP ini, berdasarkan model inquiry, ada beberapa tahap yang harus dilalui siswa, yaitu:

1. Mengamati, yaitumencermatidan memberikan contoh kegiatan transformasi geometri yang ada di sekitar.

2. Menanya, yaitumendiskusikan tentang kegiatan transformasi geometri yang dicontohkan oleh temannya

3. Menalar, yaitu memberikan masalah dan meminta siswa memikirkan solusinya dengan memberikan petunjuk tentang aplikasi matematika yang bisa digunakan.

4. Mencoba, yaitu mengunduh dan mengeksplorasi aplikasi Geogebra khususnya pada fitur transformasi geometri yang mana adabeberapa tipe yaitu translasi(perpindahan), refleksi (pencerminan), rotasi (perputaran) serta dilatasi (perbesaran)(hanafi et al., 2017)sesuai dengan petunjuk dari guru.

Contoh penggunaan aplikasi Geogebra pada smartphone pada materi Refleksi

a. Siswa diminta membuka aplikasi Geogebra pada smartphonenya dan membuka fitur tentang

Transformasi Geometri, maka akan muncul seperti gambar 4a.

b. Siswa diminta mengubah pengaturan agar tampil koordinat Cartesius, maka akan muncul seperti gambar $4 b$.

c. Kemudian siswa membuat segitiga sembarang dengan fitur "polygon".Klik Polygon, klik tiga titik pada Tampilan(Syahbana, 20 C.E.), maka akan muncul seperti gambar 4c. 
JURNAL ANUGERAH, November 2020; Vol2(2): 83 - 92

e-ISSN 2715-8179

d. Kemudian buat garis lurus sebarang, maka akan muncul seperti gambar 4d.

e. Kemudian refleksikan segitiga ABC ke garis DE dengan fitur "Refleksi objek pada garis", maka akan muncul seperti gambar 4e.

f. Dengan prosedur yang hampir sama, maka siswa diminta untuk melakukan "Rotasi objek mengitari titik" dengan sudut $45^{\circ}$, maka akan muncul seperti gambar $4 \mathrm{f}$.

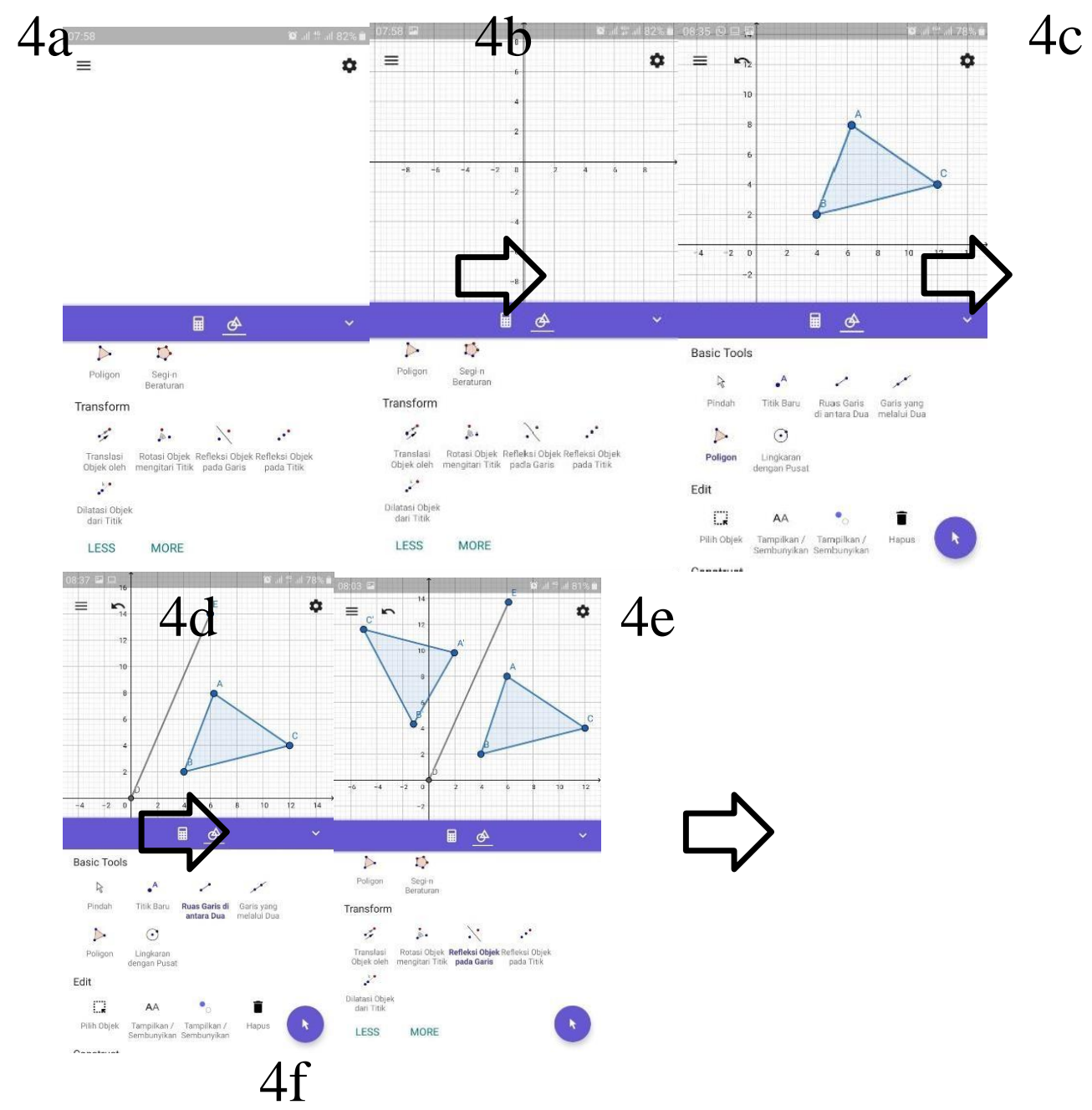




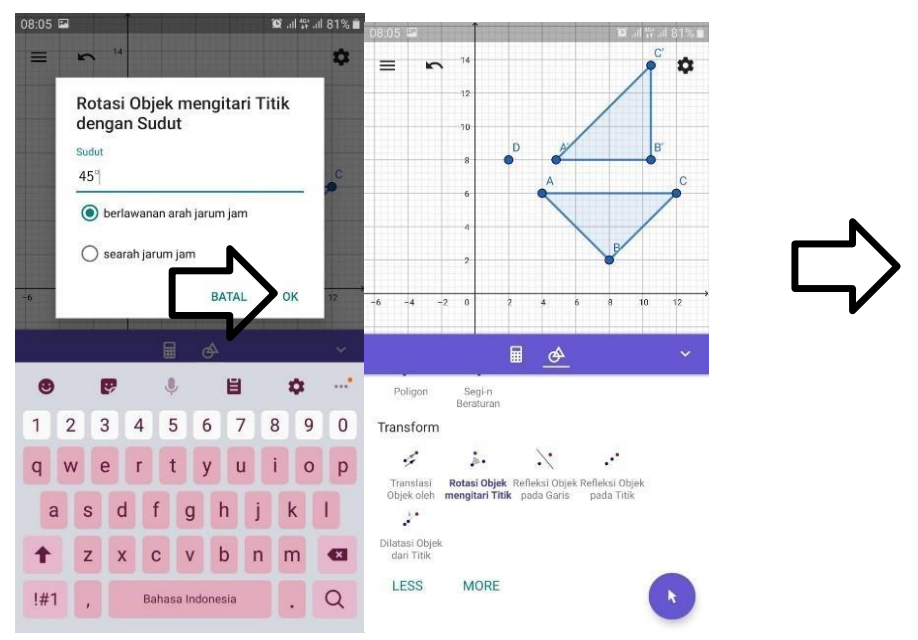

Gambar 4. Penggunaan aplikasi Geogebra pada smartphone untuk melakukan rotasi pada segitiga

sebarang.

5. Mengasosiasi, yaitu meminta siswa mengekplorasi fitur - fitur lain dari transformasi geometri yang ada pada Geogebra dengan dasar contoh yang telah dicoba dan kemudian menyusun petunjuk penggunaan masing - masing fitur transformasi geometri pada aplikasi tersebut. Karena software ini dapat juga dikembangkan tidak hanya untuk pencerminan tapi juga rotasi, dilatasi dan lainnya (Hidayatullah, Muh Tamimuddin \& Karim, 2015), sehingga siswa harus mempelajari semuanya.

6. Mengomunikasikan, yaitu mempresentasikan hasil eksplorasi melalui petunjuk yang disusun kepada teman lainnya dan berdiskusi.

\section{Pertemuan 3: Uji Coba Rencana Pelaksanaan Pembelajaran dan Evaluasi kegiatan}

Kegiatan ini dilaksanakan pada tanggal 15 November 2019 di kelas XI IPA 1 yang diampu oleh Guru Bidang Studi Matematika, Yulida Ekawaty, S.Pd, M.Si pada jam 13.00 - 14.40. Pembelajaran diawali dengan penjelasan secara singkat materi transformasi geometri beserta contoh - contohnya (translasi, refleksi, rotasi dan dilatasi), kemudian siswa diminta untuk mempraktikkan contoh - contoh tersebut dengan Geogebra. Penggunaan Geogebra disini menggunakan smartphone sehingga semua siswa bisa melakukannya. Pendampingan dilakukan secara intensif kepada siswa baik oleh Guru, Mahasiswa STTA (asisten) dan tim penulis. Siswa sangat antusias dalam mengeksplorasi aplikasi Geogebra ini seperti yang terlihat pada gambar 5 .

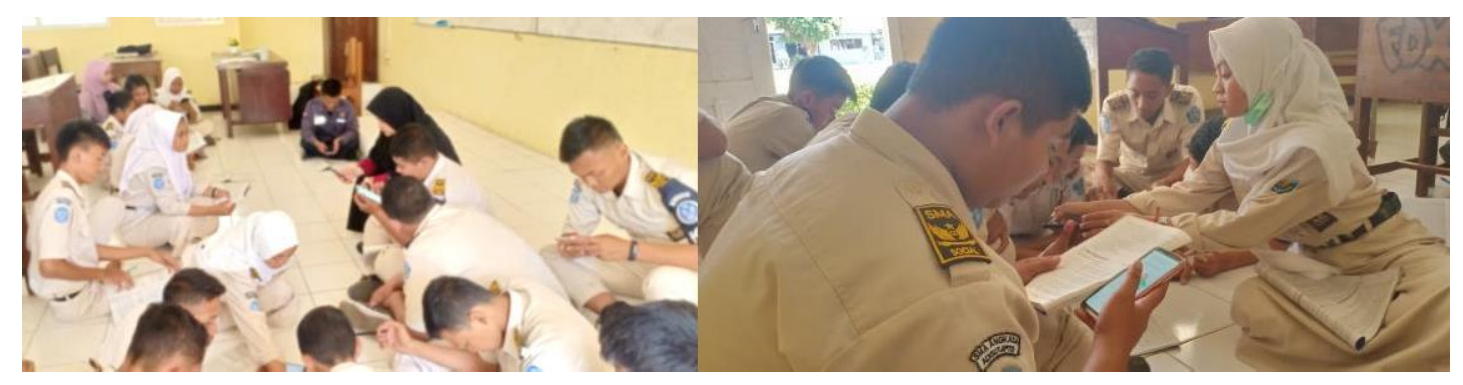

Gambar 5. Uji Coba kegiatan pembelajaran berbasis teknologi di kelas 


\section{JURNAL ANUGERAH, November 2020; Vol2(2): 83 - 92 \\ e-ISSN 2715-8179}

Kemampuan siswa saat ini dalam menjelajahi dunia teknologi tidak perlu diragukan lagi, hanya dalam hitungan detik siswa sudah berhasil mengunduh dan menginstall aplikasi Geogebra di smartphone masing - masing. Kendala terbesar hanya pada kuota dan sinyal lemah di daerah sekitar sekolah mereka. Akhirnya penulis membawa wifirouter tambahan yang sudah terisi kuota beberapa GB dan mempersilahkan siswa mengakses wifi tersebut. Fitur - fitur aplikasi yang ada pada aplikasi Geogebra yang sederhana membantu siswa untuk memahami penggunaannya. Diskusi antar siswa terjadi secara spontan dalam pembelajaran ini, jumlah siswa yang sedikit dalam satu kelas membantu guru, penulis dan asisten mahasiswa untuk lebih menyatu dalam mendampingi siswa. Suasana kelas sengaja dibuat lesehan, tidak duduk di bangku, agar nyaman dan tidak kaku. Penggunaan software Geogebra ini sesuai dengan penelitian sebelumnya (Faizah \& Astutik, 2017) terlihat dapat meningkatkan motivasi belajar siswa. Apalagi siswa dapat menggunakan smartphonenya secara bebas pada saat pembelajaran tidak perlu mencuri - curi kesempatan lagi. Tetapi hal ini juga perlu pengawasan dari guru agar siswa hanya menggunakan smartphone tersebut untuk mempelajari Geogebra alih - alih membuka media sosial atau melakukan chatting.

\section{Kesimpulan}

Secara umum kegiatan pelatihan berhasil membantu guru-guru di SMA Angkasa untuk menyusun Rencana Pelaksanaan Pembelajaran yang bersinergi dengan teknologi terkini (digital learning pada smartphone) sehingga dapat mengurangi stigma negative penggunaan smartphone selama pembelajaran. Selain itu, temuan bahwasoftware Geogebra dapat meningkatkan motivasi belajar siswa, pada kegiatan initercermin dari ketertarikan yang tinggi dari siswa pada saat uji coba pembelajaran dengan menggunakan aplikasi Geogebra melalui smartphone siswa. Siswa sangat antusias dalam membicarakan fitur - fitur pada aplikasi yang secara tidak langsung berbalur dengan konsep - konsep transformasi geometri. Hanya saja masalah kuota internet dari masing - masing siswa, koneksi Wifi maupun koneksi jenis kartu (XL, IM3, Telkomsel dll) menjadi salah satu kendala dalam kegiatan ini.

\section{Saran}

Untuk pengabdian masyarakat lebih lanjut sebaiknya dilakukan pengoptimalan teknologi baik smartphone atau aplikasi berbasis komputer dalam pembelajaran dikelas dengan materi lainnya. Pilih aplikasi yang gratisdan bisa diakses secara offline agar tidak terlalu bergantung pada kuota dan sinyal. Untuk para guru, jangan takut untuk mencoba memberikan sentuhan yang berbeda pada pembelajaran dikelas.

\section{Ucapan Terima Kasih}

Penulis mengucapkan terima kasih kepada Sekolah Tinggi Teknologi Adisutjipto (STTA) Yogyakarta yang telah memberi dukungan dana terhadap program pengabdian masyarakat ini melalui program pengabdian masyarakat internal STTA.

\section{Referensi}

Agung, S. (2018). Pemanfaatan aplikasi eogebra dalam pembelajaran matematika SMP. Seminar Nasional, $03,312-322$.

Asngari, D. R. (2015). Penggunaan geogebra dalam pembelajaran geometri. Seminar Nasional Matematika Dan Pendidikan Matematika UNY, 299-302.

Faizah, H., \& Astutik, E. P. (2017). Efektivitas lembar kerja siswa (lks) berbantuan software geogebra pada materi program linier. Jurnal Pendidikan Matematika Dan Matematika, 3(2), 103-110. jurnal.umj.ac.id/index.php/fbc

Funny, R. A. (2019). Prompting the use of online application on smartphone (integral calculator) in learning integration techniques. Journal of Physics: Conference Series, 1200(1). https://doi.org/10.1088/1742- 
$6596 / 1200 / 1 / 012017$

Hanafi, M., Wulandari, K. N., \& Wulansari, R. (2017). Transformasi geometri rotasi berbantuan software geogebra. Fibonacci Jurnal Pendidikan Matematika Dan MAtematika, 3(2), 93-102.

Hidayatullah, Muh Tamimuddin \& Karim, A. (2015). Pemanfaatan aplikasi geogebra untuk pembelajaran matematika dasar. Open Journal of Orthopedics, 238.

Oktaviani, D. N., \& Sholikhakh, R. A. (2018). Implementasi blended learning pada mata kuliah geometri transformasi.Procediamath, http://www.syekhnurjati.ac.id/jurnal/index.php/semnasmat/article/view/3258

Syahbana, A. (20 C.E.). Belajar Menguasai GeoGebra (Program Aplikasi Pembelajaran Matematika).

Tindell, Deborah R; Bohlander, R. W. (2012). The use and abuse of cell phones and text messaging in the classroom: A survey of college students. College Teaching, 60(1), 1-9. https://www.tandfonline.com/action/showCitFormats?doi=10.1080\%2F87567555.2011.604802

Utami, A. N. (2019). Dampak negatif adiksi penggunaan smartphone terhadap aspek-aspek akademik personal remaja. Perspektif Ilmu Pendidikan, 33(1), 1-14. https://doi.org/10.21009/pip.331.1 
JURNAL ANUGERAH, November 2020; Vol2(2): 83 - 92 e-ISSN 2715-8179 